DOI https://doi.org/10.18551/rjoas.2017-05.15

\title{
THE GOVERNMENT ROLE IN DEVELOPMENT MODEL OF THE MARKET, ENTREPRENEURIAL ORIENTATION ON BUSINESS PERFORMANCE AND THE INNOVATION AS MEDIATING
}

\author{
Andika Endrik \\ Post-graduate Program, Faculty of Administrative Science, University of Brawijaya, \\ Indonesia
}

Suyadi Imam, Afrianty Tri Wulida

Faculty of Administrative Science, University of Brawijaya, Indonesia

*E-mail: andikaendrik90@gmail.com

\begin{abstract}
This study was proposed to knowing the effect of market orientation and entrepreneurial orientation toward business performance on Small and Medium Enterprises (SME's) with the government role. Besides, in order to know the role of innovation as the mediator in the current study. The population in this study is SME of the ornamental plants in Batu City, East Java, with the total sample of 79 respondents. The technique sampling uses the proportional simple random. PLS (part least square) is used to do the further research. The result shows that market orientation has significant effect toward innovation. Entrepreneurial orientation has significant effect toward innovation. Market orientation has significant effect toward business performance. Entrepreneurial orientation is not significant toward business performance. Innovation is significant toward business performance. Then, the government role is significant toward business performance.
\end{abstract}

\section{KEY WORDS}

Market orientation, entrepreneurial orientation, innovation, business performance, government role, small and medium enterprises (SME).

During this time the economic resilience a country particularly Indonesia is played by the big companies, a cooperative and Small and Medium Enterprises (SME). The big company as the developmental agent, cooperative as the economic agent which as the characteristic of Indonesia that democratic and kinship based, and the SME as the business actors with the largest amount in Indonesia (Longenecker, 2009). Tambunan (2002) stated that small enterprise able to employ more labor than the big enterprise. The role of small enterprise in the employ of more labor becomes the buffering of public's welfare. Another role of small enterprises was stated by Martowardjojo (2016) the SME in Indonesia contributed to Gross Domestic Product (GDP) as $60.3 \%$.

The small enterprise in Indonesia become one of the economic sector that able to survive in economic fluctuation. Hubeis (2009) stated that during economic crisis in 19982000 in Indonesia, the small enterprise show the succeed to standing by the impact of economics crisis and the rupiah exchange rate against the dollar is soaring. At the work termination moment that was conducted by the big enterprises due to the economic crisis, the small enterprise become an economic support that still standing up and able to employ the labor who was got the work termination. By doing so, its seen that the role of the small enterprise in the informal sector as one of the necessary economic resilience to a country. The reality that happen on small enterprise in Indonesia, the rapid growth of small enterprise not followed by the high competitiveness either domestically or globally, its happen due to the market agent is less focus on market needs. The necessity of market re-orientation on small enterprise is the challenge that have to realized on the higher competitiveness achievement. The market orientation has a meaning that on market orientation needs the 
knowledge about the type of market that will be entered, include the characteristics on it (Narver and Slater, 1990).

The achievement process of knowledge toward the market needs is necessary to cultivate an entrepreneurship spirit toward the small enterprise actors. Suparyanto (2012) stated that the entrepreneurship spirit can be possessed as a carrier since birth and can be established through the education process and experience as well. It was suitable with the Psychological Theory of Entrepreneurship that emphasizes the importance of psychological characteristics in entrepreneurship. The entrepreneurship is the development process of a creative and innovative attitude that is made as a basic, method and resources to find the opportunity to achieve the success (Hubeis, 2009). During the activity to make a new business or ongoing. The small enterprise actor at least has an entrepreneurship orientation such as the desire to achieve the goal, brave to take the risk, and able to utilize new ideas integrated with the resources owned, and personal imagination, so able to make a big difference. They do not only make the effort as a way to survive in daily life.

Having an attitude toward the entrepreneurship orientation can create a new innovation or idea by the actor's thought. Innovation is the knowledge transformation to a product, process and new service as the action to use something new (Rosenfeld, 2002). Innovation is the success of exploitation by a new idea or with other words, it is knowledge mobilization, technique skill, and experience to create a product, process, and new service. The view that has to be owned by the small enterprise actor related to the market orientation, entrepreneurship orientation, and innovation. It will be more maximal if supported by the government role which as the country promoter that is able to form the small enterprise more competitive for the economic resilience locally. This matter is suitable with the opinion of Hakim (2003) which stated that the performance of society's entrepreneur will be maximal if the government can to support the infrastructure needs completely. The right policies for small enterprises related to support in the form of facilities or infrastructure that should be targeted to small enterprise. The establishment of the training organization and small enterprise development as well as facilitate permits, in order to obtain the business capital will be more beneficial for the small enterprise development.

The main point in the targeting of quality achievement of small enterprise is performance. The measurement of small enterprise performance not only instantly but also future orientation with the stability growth by year to year and able to face the new competitor. Business performance not only focuses on increasing of financial but specifically increase in non-financial has to be a concern as well. It was suitable with Indriarti ningtyas (2009) which stated the performance of an organization or a business was defined as the direction an organization to take an action to compete with another organization in one industry, not only on the financial indicator but also on the indicator of non-financial as well. Non-financial indicator covered the additional or market target, market loyalty, consumer satisfaction, or the confidence of the small enterprise actor (Zulkiffli and Perera, 2009).

The current study is developed by the theory that linked with the market orientation which related on the small enterprise with two points of view. These are behavior viewpoint (Kohli and Jaworski, 1990) which stated the market orientation as the set of going on activity to improve the consumer satisfaction. Furthermore, cultural viewpoint, according to (Narver and Slater, 1990), it defined as the collective values and conviction in a company that placed of consumer interest upon everything. Also, the current study is developed by the gaps of existing study, the study was conducted by Kraus et al.,(2012) and Carol and Mavis (2007) that showing the relationship between entrepreneurship orientation and innovation toward the business performance has an insignificant effect. But, on the others study such as Hoq and $\mathrm{Ha}$ (2009) and Mahmoud and Hanafi (2013) revealed the significant effect. The result of the previous study which still obtains the contrast result used to be the gaps in the current study.

The growth of SME in Indonesia followed by the growth of other potential regions, it's like in Batu city, East Java. The popularity of Batu city as the tourism city has a positive impact on the society around, the impact is the more of the small enterprise actors emerge. Along with the increase of Batu city image as the tourism city had emerged the various 
opportunity of new business, particularly the ornamental plant business that derived by surrounding natural potential or society innovation. As the tourism city, the progress of the ornamental plant not inferior to the vegetable and fruits as the society's agricultural products. One of the region that become the center of ornamental plant cultivation in Batu City is Sidomulyo village which mostly there was various of flower in every resident home. The potential of flower cultivation in Sidomulyo village had been there since colony era. The main product flower type is rose and another flower type able to growth fertile in this tourism city.

The large of potential in ornamental plant product, it able to become the opportunity to the small enterprise actor. Even though, the popularity of ornamental plant as the commercial matter not yet to become too high. There are many factors that affected an ornamental plant become a reasonable commercial commodity. According to department of tourism Batu city (2016) it was caused by 1) the diversity and uniqueness of flora that has an opportunity to be empowered as the commercial commodity, 2) the using of technology facilitating of ornamental plant business on the cultivating and marketing, 3) the effect of trend due to the lifestyle of society toward the needs of ornamental plant.

The problem that found often about the small enterprise in Indonesia is the focus less on market needs (Tambunan, 2008). The small enterprise actor only utilized the natural resources in the surrounding environment, without has a prediction on market. If it has been seen by the large potential of the ornamental plant in Batu city, should be maximized as one of excellent product on Batu tourism city. Besides another tourism that has been existing. But, the large potential for ornamental plant sector yet to become one of excellent product and exclusive product of Batu city. Observing by the others Indonesia region that have ornamental plant industry, the large potential of Batu city to make the ornamental plant as the new identity with endorsement of tourism city. If Netherland has the ornamental plant producer name that famous in the world, its possible Batu city become the center of ornamental plant in Indonesia.

The activity of ornamental plant industry should be market oriented, the actor of small enteprise needs the entrepreneurial attitude. The market orientation and entrepreneurial able to improve on the ornamental plant sector, for example the service to the costumer and the costumer needs that not only buy the ornamental plant but also provide the professional decoration service that not owned by the competitor. The development of the small enterprise will be better if the entrepreneurial attitude able to create the new ideas in innovation form. The intended innovation is like the utilization of ornamental plant made to the other product such as extract rose beverages and jasmine oil perfume, or the cultivation way to make an ornamental plant live longer.

\section{LITERATURE REVIEW}

Market orientation. Schalk (2008) stated the emphasized of bussiness competition on globalization era have been switched to the ability to allow the business to gift the best value to the costumer consistently. The giving value to the costumer able to do through market orientation. Kohli and Jawroski (1990) defined the market orientation as the attitude on an entrepreneur to focused their self on the need $s$ and costumer expectation, besides focuses on the competitor condition. Focus on the costumer and competitor require an entrepreneur to create an innovation based on the marketing principles. Marketing has a strong concept as the handbook to the entrepreneur to make a business decision. The marketing concept reveal that a business have to formed based on the desire and the current costumer needs or in the future, not formed by the desire and the own entrepreneur needs.

Basically the market orientation concept consist of three elements, they are market intelligence to obtain the variety of appropriate information; intelligence dissemination which the information is of is directed to the entire party in a company to get the synergy of the strategy; also responsiveness upon the market intelligence that come from a whole part on marketing strategy that suitable with the existing of market environment. According to Kraus et al (2012) market orientation provide a stimuli to an entrepreneur in make an innovation 
based on marketing concept. That is mean market orientation able as the basic to make an innovation related with the owned industry.

$\mathrm{H} 1$ : Market orientation has significant effect toward innovation

Entrepreneurial Orientation. Entrepreneurial is an intangible culture, an ability structural non fiscal that able to moved a fiscal matter. Entrepreneurial combine four produce factors, they are land, labor, capital, and skill (Sumarsono, 2010). The classification of entrepreneurial according to Lumpkin and Dess (1996) consist of two main points. First, on entrepreneurial orientation will be found the brave to take a risk that attached to an entrepreneur. Second, the pro-active attitude on business is one of characteristics of an entrepreneur. The two attitudes above are the internal factor on personal of a person that differ on every individual to respond. Mahmoud and Hanafi (2013) stated that the attitude of brave to take a risk and pro-active close related with the decision to make an innovation such as entrepreneur thought. Besides Hoq and $\mathrm{Ha} \mathrm{(2009)}$ also stated that innovation is the result of creation by an entrepreneur that always responsive toward the growth of environment condition. That matter means there is a relation between entrepreneurial orientation toward innovation.

$\mathrm{H} 2$ : Entrepreneurial orientation has significant effect toward innovation

Innovation. Porter (1990) one the famous pioneer to discuss the related philosophy with marketing concept on business administration field, determining that company has two basic functions, these are marketing and innovation. In the current context, there is a tendency to the market orientation discussion and innovation that made collectively. The impact of market orientation on a marketing literature toward business performance able to accept clearly (Kohli and Jawroski, 1990). Means that re-orientation of market help to determine the proper policy to the business actor, where the chosen of strategy in marketing field will give effective impact to support the business performance. The result of the previous study of Carol and Mavis (2007) show that the real innovation is creative work by the group of persons, the idea, and object that occur through a community are called technology brokering. This process really strong influence to do re-combination of innovation with solving either the distance or the gaps on the existing network simultaneously. Based on this relationship then the hypothesis in this study as stated bellow:

$\mathrm{H} 3$ : Market orientation has significant effect toward business performance

The role of entrepreneurial orientation becomes one of support the maximum performance business. That's suitable with the statement of Baker and Sinkula (2009) that entrepreneurial orientation will direct the improved company performance. By the business actor, has an entrepreneurial orientation spirit able to become a competitive advantage. This matter was supported by the previous study of Wu et al., (2008) found that entrepreneurial orientation gives the positive impact on company performance. Based on this relationship then the further hypothesis in this study as stated bellow:

$\mathrm{H} 4$ : Entrepreneurial orientation has significant effect toward business performance

Innovation is the source of potential competitive advantage which secures the service and used a tool to compete with a competitor (Hult et al., 2005). Innovation has an important role in obtaining competitiveness by an organization through linkages with the economic activity that is described in either financial performance or non-financial (Carol and Mavis, 2007). Innovation is perceived as the commercialization process and extracting of value by the ideas and conversing the benefit in the real market. The intended benefit is the result of the business performance that more advantage than the competitor. Based on the relationship description above, then another hypothesis in this study as follow:

H5: innovation has significant effect toward business performance

Kohli dan Jaworski (1990) defined the market orientation as the set of attitudes that ongoing and the related activity with the searching information about the market needs. Fritz (1996) found that market orientation necessary to the company's success. On the other hand, Narver and Slater (1993) seeing the innovation as one of the core value to create the ability to support the relationship of market orientation performance. According to Zaltman et al., (1973) proposed that innovation is a media to the business's success that built by intelligence collectivity and decision making properly. Besides Deshpande, Farley, and 
Webster (1993) speculating on the strong relationship between market orientation and innovation to achieve the superior business performance results. Similarly to Henard and Szymanski (2001) focuses on the empiric works that show the market orientation give the contribution of new product succeed.

The challenge to faced by the small enterprise is how to face the competition in the business environment that uncertainty. The change of business environment requires the small enterprise to renew the workings continuously in order to adapt to the challenge and environmental change. The factors of entrepreneurial consist of the pro-active attitude and brave to take a risk able to affect the increase of a person innovation (Jimenez and Valle, 2010). The study of Damanpour (1998) revealed that business performance as the final result depends on the high innovation grade. If the small enterprise able to increase the entrepreneurial orientation, then innovation will appear variously that useful to improve the performance. Hassim et al., (2011), and Madhousi et al., (2011) also explain that entrepreneurial orientation will stimuli an entrepreneur to more concern toward surrounding environment with the problem and experience, able to create the innovation that makes the advantage to the business.

Business Performance. According to Zulkiffli and Perrera (2009), business performance is defined as the operational ability to fulfill the desire of the major shareholders of the internal company, and it should be valued to measure the organization achievement. Besides, Zulkiffli and Perrera (2009) categorized the business performance become two large fields: operational business performance and strategy business performance. The operational business performance is defined as how the small enterprise actor improve the performance internally, which cover the human resources, increase the market segmentation, or maintenance the good relationship with the customer. While strategy business performance covered the increased of business achievement that had values in the financial matter that useful to attract the investor or increase the selling business value.

The government role. The crisis economic that happened some years ago gift evidence that SME sector able to survive to face the crisis. The government role takes a part in the economic improvement which through the policy was made to integrate each other on all of the economic actors. Hakim (2003) mentioned that the society entrepreneur performance able to be maximal if the government support the infrastructure needs completely. In order to the SME policy able to run smoothly, the government should be involved the SME actor in every process and policy implementation. Tambunan (2008) stated through the government supporting either by the business capital or training able to growing the small enterprise actor who has the entrepreneurial orientation to realized the business performance with high competitiveness.

H6: the government role has significant effect toward business performance

\section{RESEARCH METHODS}

The research method that used in the current study is explanatory research. The sample that used as 79 SME ornamental plant on Batu city, East Java. The current study using PLS (Partial Least Square) analysis with analytic hierarchy process (AHP). The questionnaire is distributed with semantic scale measurement with the range scale by 1 to 7 . The market orientation measured with 8 items that are developed by Schalk (2008) and Mahmoud and Hanafi (2013), entrepreneurial orientation is measured with 6 items which adapted by Lumpkin Dess (1996) and Wiklund (2007), innovation is measured with 7 items which developed by Carol and Mavis (2007), the government role is measured with 4 items which developed by Frank (2010), and business performance is measured with 10 items which adapted by Zulkiffli and Perera (2009). The conceptual model of the current study is described in the following Figure 1. 


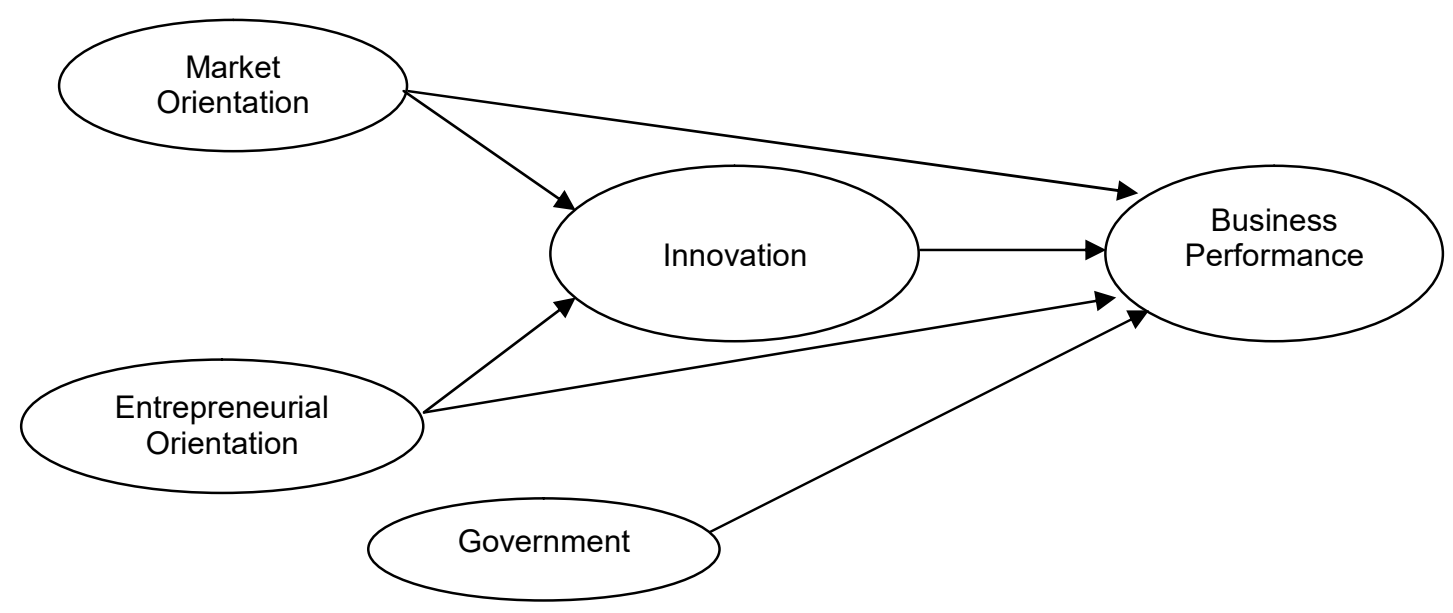

Figure 1 - Research Framework

\section{RESULTS AND DISCUSSION}

The technique to analyze the data in the current study is using partial least square (PLS). In the PLS testing statistically, in every relationship, the hypothesized is done by using the simulation that done by bootstrap methods toward the sample. The testing with bootstrap is intended to minimalize the abnormal problem of the research data. The result of the testing with bootstrapping able to see on Table 1.

Table 1 - Path Coefficient (Mean, STDEV, T-Values)

\begin{tabular}{|c|c|c|c|}
\hline Variable & Original Sample (O) & Standard Deviation (STDEV) & T Statistics (|O/STERR|) \\
\hline $\mathrm{X} 1->\mathrm{I}$ & 0.433 & 0.1338 & 3.2354 \\
\hline $\mathrm{X} 2->\mathrm{I}$ & 0.2797 & 0.1206 & 2.32 \\
\hline $\mathrm{X} 1->\mathrm{Y}$ & 0.424 & 0.1178 & 3.5984 \\
\hline $\mathrm{X} 2->\mathrm{Y}$ & 0.1573 & 0.1257 & 1.251 \\
\hline $\mathrm{I}->\mathrm{Y}$ & 0.3348 & 0.1097 & 3.0516 \\
\hline $\mathrm{G}->\mathrm{Y}$ & 0.3603 & 0.0974 & 3.7011 \\
\hline
\end{tabular}

Source: PLS analysis.

Notes: $X 1=$ market orientation, $X 2=$ entrepreneurial orientation, $I=$ innovation, $Y=$ business performance, $G=$ government.

So that, able to conclude that the result of analysis toward the hypothesis testing of $\mathrm{H} 1$, $\mathrm{H} 2, \mathrm{H} 3, \mathrm{H} 5$, and $\mathrm{H} 6$ is accepted, while $\mathrm{H} 4$ is rejected.

Hypothesis 1 revealed that market orientation (X1) has significant effect toward innovation with path coefficient value as $0.433 \mathrm{P} \leq 0.005$. Market orientation able to create the innovation that reaches out the customer needs. The small enterprise that innovated base on the marketing concept able to make the small enterprise performance better since the innovation that based on the marketing able to fulfill the needs and customer expectation. The result of this study similar with previous study of Hoq and Ha (2009) which stated market orientation has significant effect toward innovation. The small enterprise of the ornamental plant in Sidomulyo village that has market orientation able to create the new idea to compete in ornamental plant market. Furthermore, Kohli and Jawroski (1990) stated theoretically market orientation is the way of view toward the growth of the existing market so that a person have to focuses on the competition on the market. The way of view on the market able to create the innovation in order to compete to grab the new market or maintain the obtained market. The innovation that able to do is like making the various ornamental plant and fruits seeds, then packing on attractive plastics bag and modern like candy's packaging, which includes the direction how to plant the seeds. The created innovation is the potential step to respond the competition strategy understanding to the expectation and customer needs as well. 
Hypothesis 2 revealed that the entrepreneurial orientation has significant effect toward innovation with the value as $0.280 \mathrm{P} \leq 0.05$. The small enterprise in Indonesia has the strict competition. So that the entrepreneur required to do innovation in their business continually. The result of this research similar with the previous study of Hoq and $\mathrm{Ha} \mathrm{(2009)}$ which stated that entrepreneurial orientation has significant effect toward innovation on small enterprise directly. Also, the previous study of Lumpkin and Dess (1996) stated that entrepreneurial orientation is the attitude or the entrepreneur spirit that owned a person to improved their business performance. The current study show that the small enterprise of the ornamental plant on Sidomulyo village competes to get more connection with the customer, either who come directly or accept the order from the others city. The actor of small enterprise more proactive and brave to take a risk required each of the small enterprise actor to think innovatively in many ways, example expanding the supplier connections, alliances with similar industry, and build up the good relationship with the customer which is something reasonable to do.

Hypothesis 3 revealed that market orientation has significant effect toward business performance with coefficient value as $0.424 \mathrm{P} \leq 0.05$. Focusing on the customer and competitor able to maintain or improve the small enterprise performance, since with market orientation the small enterprise able to fulfill the customer needs on the right target with the business concept that is run. The study of Mahmoud (2013) on the SME on Ghana similar with the current study result. The current study obtains the market orientation by a small enterprise of the ornamental plant on Sidomulyo village has significant effect toward business performance. Despite it is still identic with the finished ornamental plant, the small business actor more brave to increase the selling such as flower vase, the various of ornamental plant decoration media. Besides also brave to receive the order in large quantities and shipping to the cross area, cross-province, even cross country. Besides, the views to the existing competitor in the similar industry on one area in Sidomulyo village is strict, which is consist of three districts. For sure that is causing the strict competition among the ornamental plant business actor. The differences of the capital amount, human resources, cultivation system, and customer connection, required the small enterprise actor to conduct the strategy to improve their business performance.

Hypothesis 4 revealed that entrepreneurial orientation has an insignificant effect toward business performance with the coefficient value as $0.157 \mathrm{P}<0.05$. Entrepreneurial orientation consists of the attitude of brave to take a risk and pro-active as well, that matter is the internal factor the small enterprise actor that not all have same personal to survive improve their business. Moreover, the small enterprise in Indonesia has an education background and knowledge unequally. Sometimes the entrepreneur without business education background is succeeded, but not little the entrepreneur with the high business education background is not succeeded. That matter is the internal entrepreneur factor since the characteristics of each person are differ in the viewing their business and improve it.

Hypothesis 5 revealed that innovation has significant effect toward business performance with coefficient value as $0.335 \mathrm{P} \leq 0.05$. According to the live product cycle theory, at the mature phase, one of the ways to maintain and improve the business performance in order to keep maximal is innovation. Moreover to the small enterprise which has the various innovation able to affect the business performance surely. The current study similar with the previous study of Carol and Mavis (2007) and Hoq and Ha (2009). The ornamental plant business of Sidomulyo village has the various innovation to improve their business performance, one of that makes the technological of watering tools and provides the plant disease cleaning system and provide the prepaid fertilizer which distributed in several districts in Sidomulyo village. The fertilizer purchasing system and plant disease cleaner are intended have a similar work with the oil filling station in general. By doing so, the small enterprise actor able to improve the plant quality and make their product more durable to shipped to the various regions and of course will improve their business performance.

Hypothesis 6 revealed that the government role has significant effect toward business performance with coefficient value as $0.364 \mathrm{P} \leq 0.05$. The current study similar with the previous study of Frank (2010). The ornamental plant business in Sidomulyo village is found 
that government endorsement really helps to form the entrepreneur quality. The government endorsement is applied with providing the training and development institutions through the agriculture official with providing the ornamental plant cultivation training program which has a certain quality. The small enterprise actor not only given the training of ornamental plant cultivation but also was scouted about how to sell larger Integrated Business Service in Batu city, which the center of SME in Batu city. Through this institution, the actors of small enterprise given the training how to pack the product more effectively and sale in market effectively, besides there is a training which using e-marketing to promote their product larger. Also, provide the service to get the capital to the ornamental plant business actors.

\section{CONCLUSION}

The study result on the ornamental plant business in Batu city, East Java, have an attractive result to knowing the small enterprise condition in Indonesia generally. The impact of economic condition that required more society to start their own business creates the economic climate develop. Also, the small enterprise in Indonesia proven as the strong economic supporter toward the various crisis economic fluctuation either in national or international. One of the evidence is when the economic crisis era in 1988 in Indonesia, several big companies and Banks went bankrupt. But the small enterprise still survives and growth as the nation expectancy to improve in the economic improvement at that time. Regardless of the big role of the small business, in the several parts need to change either in the entrepreneurship or the way of view toward market needs. The education and training which helped by the government in fostering entrepreneurship will be useful to improve the orientation attitude toward the market. The orientation toward entrepreneurship able to create the innovation by the various of creative thought to support the performance and competitiveness of small enterprise in Indonesia. The current study has a limitation since the sample of respondent only the small enterprise in the ornamental plant industry only. The future research is expected has a respondent characteristic more various with the amount and type of small enterprise in Indonesia from manufacture industry, service, or others creative business.

\section{REFERENCES}

1. Baker, W.E, Sinkula, J.M. 2009. Complementary Effect of Market Orientation and Enterpreneurial Orientation on Profitability in Small Business. Journal of Small Business Management, 47(4): 443-464.

2. Carol, Y.L. \& Mavis Y.C. 2007. Does innovation lead to performance? An empirical study of SMEs in Taiwan. Management Research News, 2(30): 115-132.

3. Deshpande, R., Farley, J.U and Webster, F.E. 1993, Corporate Culture, Customer Orientation, and Innovativeness in Japanese Firms: A Quadrad Analysis. Journal of Marketing, 1(57): 23-37.

4. Frank, Herman. 2010. Entrepreneurial Orientation and Business Performance: A Replication Study. Journal of Management. p. 175-198.

5. Hakim, Supriadi. 2003. Kewirausahaan sebagai solusi kreatif. Salemba Empat; Jakarta.

6. Hoq, Mohammad Ziaul and Ha, Norbani Che. 2009. Innovativenes: Its Antecedents and Relationship to SME Business Performance. Journal of Management SMEs. p 1-7.

7. Hubeis, Musa. 2009. Prospek Usaha Kecil Dalam Wadah Inkubator Bisnis. Jakarta: Ghalia Indonesia.

8. Indriartiningtias, R. 2009. Manajemen Industri Kecil Modern. Surabaya: Trunojoyo Pers.

9. Jimenez, Daniel. And Valle. R Sanz. 2010. "Innovation, Organizational Learning Orientation And Reverse Knowledge Transfer in Multinational Companies". The Electronic Journal of Knowledge Management, 1(12): 47-55.

10. Kohli, A.K and Jaworski, B.J. 1990. Market Orientation: The Construct, Research Proposition, and Managerial Implication. Journal of Marketing, p. 1-18. 
11. Kraus, Sascha. Rigtering, Coen J.P, Hughes, Mathew and Hosman, Vincent. 2012. Entrepreneurial Orientation and the Business Performance of SMEs: a Quantitatve Study From the Netherlands. Journal of Business and Social Business Research, 1(4).

12. Longenecker, G. Justin. 2009. Kewirausahaan Manajemen Usaha Kecil Diterjemahkan Oleh Salemba Empat. Jakarta; Salemba Empat.

13. Lumpkin, G.T and Dess G.G. 1996. Clarifying the Enterpreneurial Orientation Construct and Linking it to Performance. Academy of Management Review, 1(21):135-172.

14. Mahmoud, Rosli and Hanafi, Norshafizah. 2013. Entrepreneurial Orientation and Business Performance of Women-Owned Small and Medium Enterprises in Malaysia: Competitive Advantage as a Mediator. Journal of Business and Social Science, 1(4).

15. Narver, J.C and Slater, S.F. 1990. The Effect of Market Orientation on Business Profitability. Journal of Marketing, 4(54): 20-35.

16. Narver, J.C and Slater, S.F. 1993. The effect of Market Orientation on Product Innovation. Journal of Marketing. pp. 20-35.

17. Rosenfeld. L. 2002. Small Firm Networks: a Succesful Approach to Innovation? Research and Development Management.

18. Schalk, Adrianus Philip. 2008. Effects of Market Orientation on Business Performance: Empirical Evidence from Iceland. University of Iceland.

19. Sumarsono, Sonny. 2010. Kewirausahaan. Yogyakarta: Graha IImu.

20. Suparyanto. 2012. Ekonomi Kewirausahaan. Jilid 2. Salemba Empat. Jakarta.

21. Tambunan, Tulus, 2002. Usaha Kecil dan Menengah di Indonesia: Beberapa Isu Penting, Penerbit Salemba Empat, Jakarta.

22. Tambunan, Tulus, 2008, SMEs Development In Indonesia: Do Economic Growth And Government Support Matter? IJAPS. 2(4).

23. Wiklund, Johan. 2007. Entrepreneurial Orientation, Risk Taking, and Performance in Family Firms. Family Business Review, 1(20).

24. Wu, Lin and Sai 2008. The impact of market orientation, learning orientation, innovation on Organizational Performance. National Cheng Kung University.

25. Zulkiffli, Siti Nur Atikah and Perera, Nelson. 2009. A Literature Analysis On Business Performance For SMEs-Subjective Or Objective Measures? Journal of Management SMEs. pp. 1-9. 